\author{
Maciej Biatous \\ WydZIAŁ HisTORYCZNO-SOCJOLOGICZNY \\ UNIWERSYTET W BIAŁYMSTOKU \\ E-MAIL: MACIEJ.BIALOUS@GMAIL.COM
}

\title{
PRAKTYKI CROWDFUNDINGU W SZTUCE PUBLICZNEJ
}

Zjawisko crowdfundingu, znane $\mathrm{w}$ języku polskim również jako finansowanie społecznościowe, jest formą fundowania projektów (biznesowych, naukowych, społecznych, artystycznych i innych) opartą na niewielkich, ale licznych wpłatach, zbieranych przede wszystkim za pośrednictwem społeczności internetowych. Upowszechnienie Internetu oraz powstanie pod koniec pierwszej dekady XXI w. szeregu specjalistycznych portali służących tej formie zbierania kapitału sprawiły, że crowdfunding staje się współcześnie w wielu krajach świata zauważalną i coraz istotniejszą formą finansowania oddolnych, innowacyjnych projektów, również poświęconych kulturze i sztuce [Vargas 2011]. W artykule zostanie zaprezentowany obecny stan zainteresowania tym sposobem finansowania sztuki, zarówno zagranicą, jak i w Polsce. Szczególna uwaga zostanie zwrócona na specyfikę crowdfundingu sztuki publicznej, rozumianej tutaj jako sztuka przeznaczona dla przestrzeni publicznych i w nich umieszczona [Taborska 1996: 7]. Artykuł jest również próbą odpowiedzi na pytanie, czy popularyzacja mechanizmu finansowania społecznościowego może sprzyjać rozwojowi sztuki publicznej.

\section{Idea crowdfundingu}

Crowdfunding jako pojęcie pojawił się w dyskursie publicznym w drugiej połowie pierwszej dekady XXI w. Określenia tego użyto po raz pierwszy prawdopodobnie w 2006 r., a za jego autora uważa się Michaela Sullivana, który pisał o crowdfundingu na swoim portalu fundavlog, promującym mechanizmy finansowania społecznościowego projektów opartych na vi- 
deoblogach [Castrataro 2011]. Narodziny pojęcia wiązały się ściśle ze zdobywającym w tym samym czasie popularność określeniem crowdsourcing [Mollick 2013: 2], oznaczającym wykonywanie określonych działań projektowych przez bardzo szeroką grupę ludzi, często entuzjastów rekrutowanych za pośrednictwem Internetu. Oba te pojęcia odwołują się więc do innowacyjnych form zdobywania kapitału (ludzkiego, finansowego), w oparciu o media społecznościowe i drobny wkład licznych, korzystających z niego użytkowników. Zjawiska te mogły się rozwijać dzięki upowszechnieniu tzw. Internetu 2.0, to znaczy serwisów, w których podstawową rolę odgrywają treści generowane przez ich użytkowników (współcześnie najbardziej znanymi przykładami są portale społecznościowe, takie jak Facebook) ${ }^{1}$. Do podstawowych zalet omawianych zjawisk miałoby należeć częściowe uniezależnienie oddolnych projektów od tradycyjnych mecenasów, przede wszystkim dużych i - w wielu przypadkach - niewystarczająco elastycznych instytucji, takich jak administracja państwowa, samorządy lokalne, banki czy korporacje, oraz rozproszenie kosztów projektu na możliwie najszerszą grupę ludzi, dzięki czemu niewielkie wkłady osób wspierających (backers) są w stanie unieść nawet duże i ambitne projekty. Wreszcie, crowdsourcing i crowdfunding odwołują się do tak zwanej mądrości tłumu (wisdom of the crowd), czyli przekonania, że opinie i decyzje powstające $\mathrm{w}$ dużych zbiorowościach są często bardziej racjonalne niż te, które formułują i podejmują pojedynczy eksperci $^{2}$ [Surowiecki 2010]. Tym samym, zaangażowanie się dużej liczby uczestników w pewien projekt, miałoby dawać gwarancję jego racjonalności i społecznej funkcjonalności.

Pierwsza fala stron internetowych zajmujących się zbiórkami funduszy przede wszystkim dla grup muzycznych potrzebujących pieniędzy na profesjonalne nagranie i wydanie swojej muzyki - pojawiła się w latach 2003-2006, a więc jeszcze przed samym pojęciem crowdfundingu ${ }^{3}$. Natomiast znaczący wzrost zainteresowania ideą i zwrócenie jej ku nowym sferom życia społecznego rozpoczęły się w 2009 r., wraz z pojawieniem się amerykańskiego

1 Wyraźny rozwój tzw. Internetu 2.0 rozpoczął się w połowie pierwszej dekady XXI w. Za symboliczne potwierdzenie jego wagi można uznać wybór prestiżowego tygodnika „Time”, który za człowieka roku 2006 uznał każdego użytkownika Internetu.

2 Na podobnym przekonaniu opiera się również na przykład projekt Wikipedii, czyli wirtualnej encyklopedii, powstającej na podstawie edytowalnych, stale komentowanych i poprawianych wpisów dużej grupy użytkowników.

3 Dość powszechnie uznaje się, że pierwszą akcją społecznego finansowania w Internecie była zbiórka przeprowadzona w 1997 r. przez fanów zespołu Marillion, która umożliwiła grupie zorganizowanie trasy koncertowej w Stanach Zjednoczonych [Golemis 1997]. 
portalu internetowego Kickstarter, służącego jako platforma do społecznościowego finansowania szerokiego wachlarza projektów. W ciągu pięciu lat działalności Kickstarter znacząco się rozwinął i stał się światowym liderem serwisów crowdfundingowych. Pomiędzy 2011 a 2013 r. liczba internautów zaangażowanych w finansowanie projektów poprzez ten serwis wzrosła przeszło trzykrotnie i przekroczyła liczbę trzech milionów osób. W tym samym czasie, suma wpłat przechodzących przez portal wzrosła blisko pięciokrotnie i w 2013 r. wyniosła ok. 480 milionów dolarów. Oznacza to, że każdego dnia internauci zasilali projekty twórców sumą wynoszącą średnio 1300000 dolarów. Sukcesem zakończyło się ok. 20 tysięcy zbiórek. Najwięcej funduszy na portalu Kickstarter spływa do innowacyjnych projektów z dziedziny hi-tech, branży gier komputerowych oraz muzyki popularnej. Warto więc w tym miejscu zwrócić uwagę, że współcześnie szereg opracowań - poradników dostępnych na internetowych blogach lub w formie zwartych wydawnictw traktuje finansowanie społecznościowe przede wszystkim jako model biznesowy [Steinberg, DeMaria 2012] dla młodych przedsiębiorców rozwijających tzw. start-upy, czyli najczęściej małe firmy oparte na innowacyjnym pomyśle. Niemniej w poprzednich latach poprzez tę platformę crowdfundingową udawało się fundować również ponad tysiąc projektów rocznie poświęconych sztuce. W 2012 r. suma pieniędzy przekazanych przez serwis artystom (włączając muzyków, autorów filmów, książek i komiksów), przewyższyła nakłady amerykańskiego Narodowego Funduszu Artystycznego (NEA, National Endowment for the Arts), agencji rządowej zajmującej się wspieraniem kultury i sztuki [Chafkin 2013: 96]. Popularność portalu przekroczyła też granice Stanów Zjednoczonych. Obecnie za jego pośrednictwem finansować można projekty powstające $\mathrm{w}$ innych krajach, również w Polsce, a osoby wspierające pochodzą z niemal wszystkich państw świata.

Serwis Kickstarter uchodzi obecnie za symbol sukcesu mechanizmu crowdfundingu, istnieje jednak więcej tego typu portali, zarówno o zasięgu lokalnym, jak i globalnym. Szacuje się, że w 2012 r. poprzez ponad 450 serwisów zebrano łącznie ok. 2800000000 dolarów [Jackson 2012: 14]. Część z internetowych platform zajmowała się obsługą szerokiego wachlarza projektów, inne ograniczały się do konkretnych typów działań, takich jak finansowanie zespołów muzycznych (np. Sellaband), wsparcie drobnych przedsiębiorców pracujących nad innowacjami (np. Microventures) albo pokrywanie nadzwyczajnych kosztów związanych z osobistym życiem jednostek, takich jak koszty leczenia lub rehabilitacji osób chorych i niepełnosprawnych (np. GoFundMe). Do największych portali zajmujących się między innymi projektami z zakresu sztuki 
publicznej, oprócz wymienionego wyżej Kickstartera, należą amerykańskie Indiegogo oraz Rockethub czy brytyjski Crowdfunder. Również w Polsce działają portale internetowe poświęcone finansowaniu społecznościowemu, choć, oczywiście, w o wiele mniejszej skali niż ich amerykańskie odpowiedniki. Największą lokalną stroną tego typu jest Polakpotrafi.pl. Działając od marca 2011 r. zebrała ona do tej pory około trzech milionów złotych na ponad 900 zakończonych sukcesem projektów $\mathrm{z}$ różnych dziedzin.

Większość portali crowdfundingowych, w tym Kickstarter, działa w charakterystycznym dla tego modelu systemie "all or nothing”, co oznacza, że twórcy projektów otrzymują pieniądze tylko w przypadku, kiedy zbiorą całość potrzebnej, założonej z góry kwoty pieniędzy. Rzadszym rozwiązaniem, praktykowanym częściowo na przykład przez serwis Indiegogo, jest natomiast możliwość wyboru systemu „keep it all” (znanego również jako „flexible funding"), co oznacza, że twórcy projektu mogą otrzymać wpłacone przez użytkowników kwoty, nawet jeżeli nie uda się zebrać zakładanej całości. Dominacja systemu „all or nothing” w znacznej mierze wpływa na specyfikę crowdfundingu i relacji, jakie wytwarzają się pomiędzy autorami projektów a wspierającymi. Zostaną one opisane szerzej w dalszej części tekstu.

\section{Specyfika społecznościowego finansowania sztuki publicznej}

Do maja 2014 r. na portalu Kickstarter zarejestrowano kilkanaście tysięcy projektów poświęconych sztuce, $\mathrm{z}$ czego niemal dwa tysiące zostało oznaczonych jako sztuka publiczna (public art). Wyświetlane na stronie zbiórki z tej kategorii stanowiły podstawę kwerendy pod kątem zakładanych celów, potrzebnych kwot oraz charakterystyki wsparcia dla projektów.

Do najczęściej powtarzających się typów przedsięwzięć należą zbiórki funduszy na wykonanie murali, pomników, rzeźb czy instalacji, mających wzbogacić konkretną przestrzeń publiczną, szersze projekty rewitalizacji przestrzeni miejskiej oraz organizowanie plenerowych wystaw i ekspozycji muzealnych (co nie zawsze pokrywa się z przyjętą tu definicją sztuki publicznej, a należy raczej do szerszej kategorii sztuki w przestrzeni publicznej [Piekarska 2009: 33]). Kwoty zbierane przez twórców na ich inicjatywy znacznie się wahają. Najmniejsze, szacowane na kilkaset dolarów, to drobne lokalne przedsięwzięcia, na przykład popularne w amerykańskich miastach zbiórki na zaprojektowanie, wykonanie i zainstalowanie w parkach lub innych ruchliwych przestrzeniach „budek z książkami”, czyli przenośnych publicznych biblioteczek. Największe stawiają sobie za cel zbiórkę kilkudziesięciu lub na- 
wet kilkuset tysięcy dolarów. Najdroższe ze skutecznie ufundowanych do tej pory projektów sztuki publicznej na portalu Kickstarter zostały wycenione na ponad 100 tysięcy dolarów. Rekordowy był projekt ustawienia w miejscowości Palo Alto - części tak zwanej Doliny Krzemowej - pomnika wynalazcy Nikoli Tesli. Pomnik ten w założeniu twórców miał pełnić nie tylko funkcje estetyczne, ale również społeczne, to jest inspirować do twórczego $\mathrm{i}$ innowacyjnego myślenia (co idzie $\mathrm{w}$ parze $\mathrm{z}$ nastawioną na nowoczesne technologie gospodarką Doliny Krzemowej) oraz skupiać wokół siebie ludzi - także w sensie dosłownym, poprzez zamontowanie wewnątrz rzeźby nadajnika bezpłatnego Internetu. Na ten cel zebrano ponad 127 tysięcy dolarów. Nowojorska artystyczna parada Mermaid Parade zebrała w 2013 r. 117 tysięcy dolarów, natomiast trzeci pod względem kosztów projekt dotyczył, na co warto zwrócić szczególną uwagę, nie Stanów Zjednoczonych, lecz Brazylii. Zakładał on kompleksowe pokrycie muralami jednej z faweli w Rio de Janeiro (koszt: blisko 117 tysięcy dolarów). Łącznie około sześćdziesięciu projektów sztuki publicznej, zlokalizowanych w przynajmniej ośmiu państwach (Stany Zjednoczone, Brazylia, Wielka Brytania, Meksyk, Kanada, Niemcy, Kenia, Polska), zostało do tej pory skutecznie zasilonych sumą przynajmniej 20 tysięcy dolarów.

Pierwszy rzut oka na statystyki związane z liczbą wspierających i sumą funduszy przechodzącą przez portal Kickstarter pokazuje, że crowdfunding rzeczywiście może stać się ważnym źródłem finansowania sztuki publicznej, szczególnie projektów nieszablonowych i autentycznie oddolnych, które często mają ograniczone możliwości finansowania ze środków publicznych (np. samorządowych). Dotyczy to nie tylko Stanów Zjednoczonych i krajów wysoko rozwiniętych, czyli tzw. Globalnej Północy, ale również państw Globalnego Południa (np. Meksyk, Kenia, Brazylia). Warto jednak zwrócić uwagę na pewne ograniczenia związane ze specyfiką modelu finansowania społecznościowego. Pobieżna analiza struktury wpłat przy najdroższych projektach sztuki publicznej na serwisie Kickstarter pokazuje bowiem, że decydująca dla sukcesu może być nie tyle duża liczba wspierających projekt małymi wpłatami, co kilka większych zastrzyków kapitału, pochodzących od hojnych fundatorów. Widać to wyraźnie na przykładzie najdroższego projektu, pomnika Tesli, który wsparły 722 osoby.

Osiem z nich włożyło w projekt łączną kwotę przynajmniej ${ }^{4} 43,5$ tysiąca dolarów, co stanowiło ponad 1/3 kosztów statui, w ten sposób decydując -

4 Jest to kwota szacunkowa, ponieważ serwis Kickstarter nie udostępnia dokładnych wartości wpłat fundatorów, a jedynie widełki sum, w których się znaleźli. 
być może - o powodzeniu całego projektu. W przypadku sześciu z 10 najdroższych (do maja 2014 r.) projektów sztuki publicznej w serwisie średnia kwota wpłaty była przeszło dwukrotnie wyższa od mediany, co pokazuje, że znacząca część wpłat pochodziła od niewielkiej grupy wspierających. Badania nad dynamiką społecznościowego finansowania projektów pokazują, że w związku z dominującym modelem zbiórek typu „all or nothing”, skłonność internautów do wkładu jest tym większa im więcej funduszy zostało już zebranych, a więc im bliżej jest do sukcesu przedsięwzięcia [Agrawal, Catalini, Goldfarb 2011: 13]. Tak więc uznać można, że powodzenie projektów, szczególnie tych większych, wzrasta znacząco, jeśli uda się przekonać do niego zaledwie kilku hojnych fundatorów bądź też - co równie powszechne - jeśli na wstępnym etapie zbiórki spłynie do przedsięwzięcia wystarczająco duży kapitał z tzw. segmentu F\&F (Friends and Family) ${ }^{5}$, czyli krewnych i znajomych, osób związanych już wcześniej z twórcami, gotowych wesprzeć ich bez względu na istotę projektu lub formę zbiórki [Agrawal, Catalini, Goldfarb 2011: 16]. Naturalnie, spostrzeżenia takie nie dyskredytują mechanizmu crowdfundingu jako takiego, zwracają jednak uwagę, że w rzeczywistości nie opiera się on wyłącznie na „mądrości tłumu”. Często sukces przedsięwzięcia zależy od precyzyjnie kierowanej kampanii marketingowej lub istniejących wcześniej więzi społecznych. Warto w tym miejscu uzupełnić, że podobne stwierdzenie skierować można również w stronę charakterystycznego dla Polski „akcyjnego” (a nie konsekwentnego, systematycznego) modelu zaangażowania społecznego i filantropii [Przewłocka 2010: 30]. Może to powodować określone skutki uboczne lub patologie. W warunkach polskich, w przypadku odpisów $1 \%$ podatku na cele organizacji pożytku publicznego, mówi się na przykład często o przesadnych nakładach organizacji na promocję własną lub o wprowadzaniu potencjalnych darczyńców w błąd (np. za pomocą darmowych programów ułatwiających wypełnianie zeznań podatkowych), [Ćwieluch 2015].

Finansowanie społecznościowe różni się jednak od tradycyjnego modelu zbiórki publicznej na konkretny cel. W przypadku zbiórek, darczyńcy zazwyczaj nie otrzymują nic w zamian, jeśli nie liczyć satysfakcji związanej ze wsparciem istotnej $\mathrm{z}$ ich punktu widzenia sprawy lub symbolicznego potwierdzenia zaangażowania $\mathrm{w}$ akcję, jak choćby w przypadku popularnych naklejek w kształcie serca, które otrzymują darczyńcy podczas corocznej akcji Wielkiej Orkiestry Świątecznej Pomocy. Tymczasem mechanizm finan-

5 Niekiedy można spotkać się również z na wpół żartobliwym określeniem 3F: Friends, Fools and Family, czyli krewni, znajomi i naiwniacy (głupcy), [por. Vargas 2011: 2]. 
sowania społecznościowego zawiera w większości wypadków pewną obietnicę wymiany. $\mathrm{Na}$ portalach crowdfundingowych twórcy projektów sami ustalają, na jakie korzyści mogą liczyć osoby, które wpłacą kwoty powyżej konkretnych progów. W przypadku projektów technologicznych lub tych przedsięwzięć ze sfery kultury, których efektem końcowym ma być produkt możliwy do mechanicznej lub elektronicznej reprodukcji (album muzyczny, film, książka itp.), taki rodzaj transakcji jest stosunkowo łatwy. Fundatorzy poprzez wpłaty uzyskują zazwyczaj szybszy, tańszy lub rozszerzony dostęp do końcowego produktu, udział w projekcie jest więc często traktowany jako swego rodzaju inwestycja. Mechanizm taki całkowicie nie przystaje jednak do projektów sztuki publicznej. Po pierwsze, korzyści z nich płynące są przede wszystkim symboliczne. Po drugie, $\mathrm{z}$ inicjatyw tych korzystają głównie społeczności lokalne, mieszkańcy okolic, w których dane dzieło sztuki się znajduje. Może to potencjalnie obniżać motywację do finansowania takich przedsięwzięć przez internautów z miejscowości i krajów oddalonych od miejsca projektu. Zachętą do wzięcia udziału w projektach artystycznych są więc, według badaczy zjawiska [Apostolos, Ioannis 2012; Ordanini, Miceli, Pizzetti, Parasuraman 2011: 32], raczej społeczne potrzeby wkładu w czyjś sukces, czyli potrzeba bycia mecenasem (desire for patronage) oraz potrzeba uczestnictwa w życiu społecznym (desire for social participation).

Oprócz zaspokajania tych potrzeb, twórcy projektów artystycznych starają się jednak również gwarantować wpłacającemu poczucie indywidualnego zysku, wykraczającego poza anonimową satysfakcję ze współtworzenia projektu. Choćby z tego powodu, że wymagają tego zasady obowiązujące na większości popularnych serwisów crowdfundingowych. Do najbardziej popularnych form gratyfikacji fundatorów zaliczyć więc można na przykład osobiste podziękowania, dyplomy i certyfikaty, czy też wymienienie nazwisk wspierających osób na tablicy sponsorów umieszczonej przy dziele sztuki. Częste są również gratyfikacje materialne, na przykład przesyłana darczyńcy fotograficzna dokumentacja projektu, publikacje na tematy z nim związane oraz inne materiały promocyjne, takie jak bluzki, płócienne torby, przypinki, pocztówki. Oczywiście ich charakter sprawia, że w większości nie mają one dużej wartości materialnej, najbardziej hojni wspierający mogą jednak zazwyczaj liczyć na wyjątkowe prezenty (np. za wpłacenie przynajmniej pięciu i pół tysiąca dolarów na pomnik Tesli można było otrzymać ponad sześćdziesięciocentymetrową, wykonaną z brązu kopię statui). Odpowiedni dobór gratyfikacji dla poszczególnych wysokości wpłacanych kwot może być kluczowy dla sukcesu projektu, zachęcając fundatorów do przekazywania 
twórcom większych sum [Palmer 2013]. Tym samym, autorzy muszą poświęcić wiele pracy i uwagi na odpowiednią promocję. Istotne są również próby nawiązania względnie trwałych i pogłębionych więzi z internautami, przekonania ich do wpłacania wysokich kwot, ale również - co niemniej cenne - do przekazywania wiadomości o projekcie dalej, wśród znajomych. Stąd też, dość powszechną praktyką, nie tylko w przypadku projektów ze sfery sztuki, jest nagradzanie najhojniejszych fundatorów osobistymi spotkaniami z twórcami projektu. Warto jednak zauważyć, że promocja może stać się również uciążliwym balastem dla inicjatorów przedsięwzięcia. Zdarza się bowiem na przykład, że zobowiązania wobec fundatorów znacznie opóźniają pracę nad samym projektem [Malone 2012: 8].

Zdecydowanie symboliczny charakter zysków płynących ze wspierania projektów sztuki publicznej sprawia, że crowdfunding sztuki uznać można za technologicznie zdeterminowane rozwinięcie idei anonimowego lub zbiorowego mecenatu sztuki, która rozwijała się w Europie od połowy XIX w. [Golka 2008: 102]. Stało za nią dążenie do uniezależnienia artystów i ich twórczości od zapotrzebowania konkretnych, prywatnych mecenasów, co w istotnej mierze wpływało na zachowawczość sztuki. Rzeczywiście, w przypadku platform finansowania społecznościowego, projekty mogą przynajmniej częściowo uniezależnić się od mecenasów instytucjonalnych. Przede wszystkim $\mathrm{w}$ sferze finansowej, bowiem artystyczne ingerencje w przestrzeń publiczną i tak zazwyczaj wymagają pozwoleń ze strony władz lokalnych. Trudno jest natomiast określić jaki rodzaj sztuki wspierany jest przez mechanizmy crowdfundingu. Sukces konkretnych projektów leży bowiem nie tylko poza opiniami ekspertów (znawców sztuki), ale - jak zostało zauważone wyżej - często również poza tak zwaną „mądrością tłumu”, która może być zwabiona kilkoma wysokimi wpłatami, na przykład od krewnych i znajomych twórcy. Szanse powodzenia projektu nie muszą więc koniecznie wiązać się ani $\mathrm{z}$ wartościami artystycznymi, ani funkcjonalnością pewnych rozwiązań $\mathrm{w}$ przestrzeni publicznej, ale $\mathrm{z}$ odpowiednio przygotowaną strategią marketingową. Noreen Malone [2012: 8], krytykując model crowdfundingu stwierdza, że w dużym stopniu służy on rozwiązywaniu „problemów pierwszego świata" (First World problems), co w tym przypadku oznacza kwestie błahe lub pozorne. Pokazuje, że duża część środków jest w istocie marnotrawiona na mało wartościowe projekty, które zdobywają fundusze dzięki wsparciu społeczności internetowych, preferujących żart i widowiskowość nad refleksję i rzeczywistą analizę potrzeb społecznych. Jako przykład takiego projektu ze sfery sztuki publicznej Malone uznała oszacowany na blisko 70 
tysięcy dolarów pomnik RoboCopa, znanego bohatera filmów science fiction, mający stanąć w borykającym się z gospodarczą i demograficzną zapaścią amerykańskim mieście Detroit.

Niektórzy obserwatorzy zjawiska zwracają również uwagę, że rosnąca popularność crowdfundingu, szczególnie w sferze kultury, może przynieść niepożądane efekty uboczne. W Stanach Zjednoczonych istnieją już serwisy, takie jak Citizinvestor, które obsługują społecznościowe finansowanie projektów proponowanych przez władze samorządowe, na które nie ma jednak funduszy w lokalnych budżetach. Z jednej strony, rozwiązanie takie sprzyjać może partycypacji obywatelskiej na poziomie lokalnym, z drugiej jednak, jego utrwalenie się może spowodować, że samorządy będą starały się stopniowo minimalizować bezpośrednie finansowanie projektów, których efekty są trudno mierzalne (np. artystycznych), starając się przerzucić koszty ich przeprowadzenia bezpośrednio na obywateli [Malone 2012: 8].

\section{Finansowanie społecznościowe sztuki publicznej w Polsce}

$\mathrm{Na}$ najważniejszych światowych portalach crowdfundingowych odnaleźć można pojedyncze projekty artystyczne twórców polskich lub tworzone w Polsce. Do największych skutecznie ufundowanych należy projekt Maki amerykańskiego artysty Billa Goulda. Jest to instalacja przedstawiająca pięć wielkich maków, którą w czerwcu 2014 r. zaczęto ustawiać na lubelskim osiedlu Skarpa, gdzie artysta mieszkał przez pewien czas w latach osiemdziesiątych [Hetman 2014]. Co ciekawe, istotną część projektu stanowiło zaangażowanie lokalnej społeczności, czyli potencjalnych odbiorców. Artysta oraz mieszkańcy Lubelszczyzny wspólnie wykonali ceramiczne płytki wykorzystane następnie do stworzenia płatków kwiatów. Artysta za pomocą crowdfundingu na portalu Kickstarter zebrał ponad 33 tysiące dolarów ${ }^{6}$.

Kolejne projekty artystyczne odnaleźć można na polskich serwisach crowdfundingowych, takich jak Polakpotrafi.pl, Wspieram.to, czy zorientowanym wyłącznie na przedsięwzięcia kulturalne Wspieramkulture.pl. Kwerenda kategorii „sztuka” na największym z nich, portalu Polakpotrafi.pl, pokazuje jednak, że stanowi ona margines wszystkich zbiórek. Do czerwca 2014 r. sukcesem zakończyło się dwanaście akcji z tej kategorii, z czego cztery uznać można za projekty z zakresu sztuki publicznej. Były to niezbyt kosztowne

6 Warto zwrócić uwagę, że choć na projekt złożyło się 165 fundatorów, to ponad 40\% zebranej sumy pochodzi od zaledwie pięciu osób. 
przedsięwzięcia, z których najdroższe - pomnik Jakuba Wędrowycza, bohatera prozy Andrzeja Pilipiuka - zostało wycenione na sześć tysięcy złotych, ostatecznie zbierając blisko 8,5 tysiąca. Trzymetrową, wykonaną z lipowego drewna rzeźbę ustawiono i odsłonięto latem 2013 r. w Wojsławicach, w województwie lubelskim. Pozostałe sfinansowane projekty, to jest pomalowanie schodów na poznańskim osiedlu Wilda, odnowienie i przywrócenie przestrzeni publicznej tzw. rzeźby Tulipana w Toruniu oraz stworzenie muralu pt. Tolerancja w krakowskiej dzielnicy Zabłocie, kosztować miały pomiędzy 1000 a 2600 złotych, były więc projektami o bardzo małej skali. W tym samym czasie na portalu Wspieramkulture.pl dominowały przedsięwzięcia związane z wydaniem książek lub płyt, przygotowaniem wystaw, filmów lub spektakli teatralnych. Część z inicjatyw, na przykład festiwale sztuki ART. eria w Częstochowie oraz Survival we Wrocławiu, dotyczyła prezentacji sztuki w przestrzeni publicznej, ale projekty poświęcone sztuce publicznej jako takiej należały do wyjątków. Jedynym odnalezionym przeze mnie bezdyskusyjnym przykładem wydaje się być zbiórka pieniędzy na neon +4822 . Pierwotnie przygotowany na konkurs Neon dla Warszawy nie zyskał uznania głosujących jako artystyczny symbol miasta, osoby wspierające ten projekt postanowiły więc ufundować go poprzez finansowanie społecznościowe. Udało się zebrać na ten cel 3800 złotych.

Kwerenda kategorii „sztuka” w lokalnych serwisach crowdfundingowych pokazuje, że działania artystyczne nie należą do najpopularniejszych kategorii projektów, w których partycypują polscy internauci. Wśród przedsięwzięć poświęconych szeroko rozumianej kulturze dominują natomiast projekty, których efektem końcowym jest możliwe do mechanicznej czy elektronicznej reprodukcji dzieło - film, album muzyczny, książka czy wystawa fotografii. Zachętą do wspierania takich projektów jest z pewnością ich zasięg, wykraczający poza konkretną, lokalną społeczność7. W związku z tym wydaje się, że w przypadku lokalnych serwisów, które nie mogą liczyć - jak globalne portale w rodzaju Kickstartera - na niemal nieograniczoną liczbę potencjalnych użytkowników, największą szansę na sukces mają niewielkie projekty sztuki publicznej, nie ingerujące zdecydowanie w przestrzeń, nie mające dużych ambicji artystycznych i nie budzące kontrowersji (choć sporna może być na

7 Warto zwrócić uwagę, że w przypadku niektórych projektów sztuki publicznej, na przykład poznańskiego malowania schodów, krakowskiego muralu Tolerancja, a przede wszystkim warszawskiego neonu, twórcy projektu zwracają się wprost do mieszkańców tych miast, zakładając zapewne, że internauci z innych miejscowości nie będą zainteresowani finansowym wsparciem tych inicjatyw. 
przykład estetyczna wartość zrealizowanego w Wojsławicach pomnika Jakuba Wędrowycza). Projekty te fundowane są prawdopodobnie przede wszystkim przez członków społeczności, do których są kierowane, czyli potencjalnych odbiorców oraz internautów z segmentu Friends and Family.

Niestety, portale crowdfundingowe nie dają wglądu w przeszłe projekty, które nie uzyskały wymaganej liczby wpłat. Trudno jest więc jednoznacznie określić, czy projekty duże, awangardowe lub kontrowersyjne w ogóle nie pojawiały się w lokalnych serwisach, czy też nie znajdowały odpowiedniego zainteresowania. Monitoring portali Polakpotrafi.pl, Wspieram.to oraz Wspieramkulture.pl od kwietnia do czerwca 2014 r. nie przyniósł jednak żadnych obserwacji tego rodzaju inicjatyw. Można więc założyć, że projekty takie, nawet jeśli się pojawiają, to jedynie sporadycznie.

\section{Zakończenie}

Model finansowania społecznościowego, wraz ze swoimi zaletami i wadami, realnie wpływa na współczesną kulturę i sztukę, również sztukę publiczną. Crowdfunding bez wątpienia otwiera nowe możliwości finansowania projektów oddolnych i niezależnych. Jednocześnie zmienia relacje pomiędzy artystą a zakładanymi odbiorcami dzieła. Wymusza na twórcach bardziej aktywny udział w Internecie, promowanie własnych pomysłów, nawiązywanie licznych i jak najbardziej trwałych relacji na serwisach społecznościowych, co jest szczególnie istotne w obowiązującym na większości portali crowdfundingowych systemie finansowania „all or nothing”. Z drugiej strony, zachęca również internautów do większej aktywności. Wsparcie finansowe konkretnego projektu z zakresu sztuki publicznej jest bowiem nie tylko wyrazem aprobaty, ale też realnym aktem włączenia się odbiorców w procesy współtworzenia przestrzeni publicznej. Wzrost popularności crowdfundingu czy crowdsourcingu sprzyjać więc może rozwojowi partycypacji obywatelskiej. Chociażby poprzez upowszechnienie udziału w procesach podejmowania decyzji o wydatkowaniu publicznych pieniędzy, na przykład w postaci tzw. budżetów obywatelskich czy partycypacyjnych, które swoją plebiscytową formułą przypominają nieco akcje crowdfundingowe.

$\mathrm{Z}$ drugiej strony, mechanizm finansowania społecznościowego ma bardzo ograniczone możliwości kontroli i wpływu na artystyczną i społeczną wartość projektów. Oparcie się na „mądrości tłumu” użytkowników Internetu może prowadzić więc do promocji inicjatyw przeciętnych, nie prezen- 
tujących wysokiej wartości estetycznej ani użytkowej, bądź też nie wiążących się ściśle z przestrzenią, w której mają się znaleźć. Istnieją również inne zagrożenia związane $\mathrm{z}$ crowdfundingiem sztuki publicznej. Wyżej zwrócono uwagę na ryzyko przerzucania tego rodzaju inicjatyw $z$ instytucji publicznych (np. samorządów lokalnych) wyłącznie na barki obywateli. Innym problemem, dotyczącym przede wszystkim projektów biznesowych, ale mogącym pojawiać się również w przypadku projektów artystycznych, jest kwestia praw własności intelektualnej. W większości przypadków, portale crowdfundingowe nie ponoszą bowiem odpowiedzialności za ochronę tych praw, a więc pomysł, który raz znajdzie się w sieci, może być następnie wykorzystywany przez innych twórców bez zgody czy wiedzy pierwotnych pomysłodawców.

Rosnące zainteresowanie crowdfundingiem $\mathrm{w}$ wielu dziedzinach życia społecznego powoduje, że obecnie w licznych krajach świata wprowadza się i przygotowuje ustawodawstwo regulujące ten mechanizm. Trwałe zagnieżdżenie się finansowania społecznościowego nie tylko w świadomości społecznej obywateli, ale również $\mathrm{w}$ systemach prawnych spowodować może, że crowdfunding stanie się w przyszłości jedną z najistotniejszych form wspierania i rozwoju sztuki publicznej na świecie, a tym samym ważnym narzędziem kształtowania przestrzeni publicznej.

\section{Bibliografia}

Agrawal A. K., Catalini Ch., Goldfarb A. (2011), The geography of crowdfunding, Cambridge

Apostolos G., Ioannis M. (2012), Crowd-funding: developing a strategy for crowd participation, Serres

Castrataro D. (2011), A social history of crowdfunding, Socialmediaweek.org http://socialmediaweek.org/blog/2011/12/a-social-history-of-crowdfunding/ [01.09.2015]

Chafkin M. (2013), Kickstarter can fund your dreams, „Fastcompany.com”, nr 4

Crowdfunding, Wordspy.com, http://wordspy.com/words/crowdfunding.asp [01.06.2014]

Ćwieluch J. (2015), Jeden procent, dziesięć zmartwień, „Polityka”, nr 16

Golemis D. (1997), British band's U.S. tour is computer-generated, „Chicago Tribune”, http://articles.chicagotribune.com/1997-09-23/features/9709230071_1_music-fans-newsgroup-marillion [01.09.2015]

Golka M. (2008), Socjologia sztuki, Warszawa 
Hetman M. (2014), Na Czubach powstanie 8-metrowa rzeźba „Maki”, „Kurier Lubelski” http://www.kurierlubelski.pl/artykul/3433629,na-czubach-powstanie-8metrowa -rzezba-maki,id,t.html [15.06.2014]

Jackson K. (2012), Crowdfunding helps kickstart projects, „PM Network”, nr 7

Malone N. (2012), Fund me, I'm useless, „The New Republic” [06.12.2012]

Mollick E. (2014), The dynamics of crowdfunding: An exploratory study, „Journal of Business Venturing", nr 29

Ordanini A., Miceli L., Pizzetti M., Parasuraman A. (2011), Crowdfunding: transforming customers into investors through innovative service platforms, "Journal of Service Management”, nr 4

Palmer A. (2013), Drinking with your fans, „New Statesman”, 25-31 października 2013

Piekarska D. (2009), [Wyjście z zamknięcia]: WY-kraczanie sztuki poza przestrzeń muzealna, W-chodzenie w przestrzeń publiczną, „Kultura Miasta”, nr 1

Przewłocka J. (2011), Zaangażowanie społeczne Polaków w roku 2010: wolontariat, filantropia, 1\%. Raport $z$ badań, http://civicpedia.ngo.pl/files/civicpedia.pl/public/raporty/zaangazowanie2010.pdf [01.09.2015]

Steinberg S., DeMaria R. (2012), The crowdfunding bible: How to raise money for any startup, video game, or project, http://www.crowdfundingguides.com/The $\% 20$ Crowdfunding\%20Bible.pdf [01.09.2015]

Surowiecki J. (2010), Mądrość tłumu: większość ma rację w ekonomii, biznesie i polityce, Gliwice

Taborska H. (1996), Współczesna sztuka publiczna. Dzieła i problemy, Warszawa

Vargas Y.B. (2011), Crowdfunding realities - an explorative study intocCrowdfunding and motivations of crowdfunding platform owners, investors and entrepreneurs, http:// www.academia.edu/3635074/Crowdfunding_Realities_-_An_explorative_study_ into_Crowdfunding_and_Motivations_of_Crowdfunding_Platform_Owners_ Investors_and_Entrepreneurs [01.09.2015] 
SUMMARY

\section{Crowdfunding of public art}

Crowdfunding is a form of funding projects (business, scientific, social, artistic, etc.) based on small but numerous payments, collected mainly through Internet communities. The article presents the current state of interest in this form of public art funding, both in Poland, and abroad. The analysis of crowdfunding websites shows several features of this mechanism used for public art funding. It encourages artists to engage in more active participation on the Internet, especially on social networks' level, which is particularly important in the all-or-nothing financing system. Crowdfunding also encourages people to be more active citizens, as financial support for specific projects in the field of public art is not only an endorsement, but also a real act of participation in the processes of creation of public space. On the other hand, crowdfunding has very limited ability to control and influence the artistic and social value of projects. Reliance on the "wisdom of the crowd" may therefore lead to the promotion of mediocre initiatives, neither presenting a high aesthetic value, nor bonded to the space in which they are to be found. There are also other risks associated with crowdfunding of public art, such as the risk of rollover of such initiatives from public institutions (e.g. local governments) solely on the shoulders of citizens, or the lack of intellectual property protection.

Keywords:

crowdfunding, Internet, public art, public space 